\title{
Ellagic acid induces cell cycle arrest and apoptosis through TGF- $\beta /$ Smad3 signaling pathway in human breast cancer MCF-7 cells
}

\author{
HONG-SHENG CHEN, MING-HAN BAI, TAO ZHANG, GUO-DONG LI and MING LIU \\ Department of General Surgery, The Fourth Affiliated Hospital of Harbin Medical University, \\ Nangang, Harbin, Heilongjiang 150001, P.R. China
}

Received November 6, 2014; Accepted December 29, 2014

DOI: $10.3892 /$ ijo.2015.2870

\begin{abstract}
Breast cancer represents the second leading cause of cancer-related deaths among women worldwide and preventive therapy could reverse or delay the devastating impact of this disease. Ellagic acid (EA), a dietary flavonoid polyphenol which is present in abundance in pomegranate, muscadine grapes, walnuts and strawberries, has been shown to inhibit cancer cells proliferation and induce apoptosis. Here, we investigated the growth inhibitory effects of EA on MCF-7 breast cancer cells. In the present study, we first found that EA inhibits the proliferation of MCF-7 breast cancer cells mainly mediated by arresting cell cycle in the G0/G1 phase. Moreover, gene expression profiling of MCF-7 breast cancer cell line treated with EA for 6, 12 and $24 \mathrm{~h}$ was performed using cDNA microarray. A total of 4,738 genes were found with a $>2.0$-fold change after $24 \mathrm{~h}$ of EA treatment. Among these genes, 2,547 were downregulated and 2,191 were upregulated. Furthermore, the changes of 16 genes, which belong to TGF- $\beta /$ Smads signaling pathway, were confirmed by real-time RT-PCR and/or western blot analysis. TGF- $\beta /$ Smads signaling pathway was found as the potential molecular mechanism of EA to regulate breast cancer cell cycle arrest in vitro. Therefore, the regulation of TGF- $\beta /$ Smads pathway in breast cancer cells could be a novel therapeutic approach for the treatment of patients with breast cancer. Further studies with in vitro models, as well as an analysis of additional human samples, are still needed to confirm the molecular mechanisms of EA in inhibition or prevention of breast cancer growth.
\end{abstract}

Correspondence to: Professor Ming Liu, The Fourth Affiliated Hospital of Harbin Medical University, Nangang, Harbin, Heilongjiang 150001, P.R. China

E-mail:mliu35@aliyun.com

Key words: ellagic acid, TGF- $\beta / \mathrm{Smad} 3$ signaling pathway, cell cycle arrest, apoptosis, human breast cancer cells

\section{Introduction}

Breast cancer is the most common cancer and the second leading cause of cancer-related death among females in the world, accounting for $23 \%$ of the total cancer cases and $14 \%$ of the cancer deaths (1), indicating that prevention and early therapy of breast cancer is needed urgently. Currently, breast cancer is treated with surgery, chemotherapy, endocrine therapy, radiation therapy and targeted therapy or multidisciplinary synthetic therapy. Although these treatment modalities are remarkable successful, a significant number of patients either do not respond to therapy, or the tumor may recur and metastasize during therapy. The unsatisfactory prognosis strongly suggests that the evaluation of novel preventive agents is urgently needed to decrease the incidence of breast cancer.

Studies have shown that ellagic acid, a dietary flavonoid polyphenol which is abundant in pomegranate, muscadine grapes, walnuts and strawberries, can inhibit cancer cells proliferation and induce apoptosis (2-5). However, the precise molecular mechanism by which EA inhibits cancer cell growth is still unknown. Understanding the molecular biological properties of EA may lead to the clinical development of mechanism-based chemopreventive and therapeutic strategies for breast cancer. The alterations of gene expression profiles by some anticancer agents have been reported $(6,7)$. In the present study, cDNA microarray can detect the changes of gene expression profiles and provide evidence for determining the effects of anticancer agents on cancer cells. We used the high-throughput gene chip, which contains $41,000^{+}$known genes to understand the potential molecular mechanism of EA on MCF-7 breast cancer cells.

It is well known that many signal pathways play important roles in the control of cell growth, differentiation, apoptosis, inflammation, stress response, and many other physiologic processes, respectively (8-11). In the present study, several genes belonging to TGF- $\beta$ /Smads signaling pathway were regulated remarkably by EA treatment in MCF-7 cells.

\section{Materials and methods}

EA and cell lines. Ellagic acid (EA) was purchased from Sigma Chemical Co. (St. Louis, MO, USA). Stock solution of 
EA ( $2 \mathrm{mg} / \mathrm{ml})$ was prepared in dimethyl sulfoxide (DMSO), and filter sterilized before use. The human breast cancer cell line MCF-7 was purchased from the Cell Bank of Shanghai Institute of Biological Sciences, Chinese Academy of Sciences (Shanghai, China). MCF-7 cells were cultured in RPMI-1640 supplemented with $10 \%$ fetal bovine serum (FBS) and $1 \%$ penicillin streptomycin solution in an atmosphere of $95 \%$ air and $5 \% \mathrm{CO}_{2}$ in a $37^{\circ} \mathrm{C}$ humidified incubator.

Cell proliferation assay. Cells were seeded in 96-well plates at a density designed to reach $70-80 \%$ confluency. Cells were allowed to adhere and $24 \mathrm{~h}$ later were treated with EA at 0,10 , 20,30 and $40 \mu \mathrm{g} / \mathrm{ml}$. After 24,48 or $72 \mathrm{~h}$ of treatment, $200 \mu \mathrm{l}$ of MTT was added to each well, and the cells were incubated for $4 \mathrm{~h}$ at $37^{\circ} \mathrm{C}$. The medium was discarded, and the dark blue formazan crystals were adequately dissolved with DMSO for $10 \mathrm{~min}$ on a rocker platform. The absorbance was measured at $570 \mathrm{~nm}$ using an ELISA reader (Tecan Sunrise, Männedorf, Switzerland). The cell viability was calculated according to: OD sample/OD control x $100 \%$. The assay was performed in triplicate.

Cell cycle analysis. MCF-7 cells $\left(5 \times 10^{5}\right)$ were seeded in $\mathrm{T} 25$ culture flasks and grew for $6 \mathrm{~h}$ to reach $50-60 \%$ confluency. Cells were starved in serum-free medium for $24 \mathrm{~h}$ to achieve synchronization. After returning to regular growth medium for $6 \mathrm{~h}$, cells were treated with EA at $0,10,20$ and $30 \mu \mathrm{g} / \mathrm{ml}$. DMSO (final concentration $<0.1 \%$ ) was used as a negative control. After treated for $24 \mathrm{~h}$ at $37^{\circ} \mathrm{C}$, floating and adherent cells were collected, washed with ice-cold PBS and fixed with $70 \%$ ethanol for at least $12 \mathrm{~h}$ at $4^{\circ} \mathrm{C}$. The cells were then treated with $80 \mathrm{mg} / \mathrm{ml} \mathrm{RNase} \mathrm{A} \mathrm{and} 50 \mu \mathrm{g} / \mathrm{ml} \mathrm{PI}$ at a density of $1 \times 10^{6}$ cells $/ \mathrm{ml}$ for $30 \mathrm{~min}$, and the stained cells were analyzed using a FACScan cytometer (Becton-Dickinson, Franklin Lakes, NJ, USA).

Cell apoptosis analysis. The apoptotic rate was measured by FCM according to the instructions provided by the Annexin V-FITC kit (Becton-Dickinson). Briefly, following treatment with $0,10,20$ and $30 \mu \mathrm{g} / \mathrm{ml}$ of EA for $24 \mathrm{~h}$, cells were harvested after digestion with $0.25 \%$ trypsin. The collected cells were washed three times with ice-cold PBS containing calcium and resuspended in binding buffer (500 $\mu \mathrm{l})$ at a density of $1 \times 10^{6}$ cells $/ \mathrm{ml}$, in which $500 \mu \mathrm{l}$ of cell suspension was added to a $5 \mathrm{ml} \mathrm{FCM}$ tube and Annexin V-FITC $(50 \mu \mathrm{g} / \mathrm{ml}, 5 \mu \mathrm{l})$ and PI $(50 \mu \mathrm{g} / \mathrm{ml}, 5 \mu \mathrm{l})$ were added. Then the cells were incubated for $30 \mathrm{~min}$ at room temperature in the dark. The apoptotic percentage of 10,000 cells was determined using FCM.

Morphology and ultra structure of apoptotic cells was observed by transmission electron microscopy (TEM). MCF-7 cells were seeded at a density of $1 \times 10^{6}$ cells/flask and treated with $15 \mu \mathrm{g} / \mathrm{ml}$ EA-supplemented medium for $24 \mathrm{~h}$. DMSO was used as a control. After incubation, cells were fixed with $2.5 \%$ glutaraldehyde in $0.1 \mathrm{M}$ sodium cacodylate buffer for $24 \mathrm{~h}$ at $4^{\circ} \mathrm{C}$. Then, the cells were washed in the same buffer three times, fixed with $1 \%$ osmium tetroxide and dehydrated in graded ethanol. The $100 \%$ ethanol solution was then replaced by propylene oxide and embedded in epoxy resin, which was polymerized at $70^{\circ} \mathrm{C}$ for $8 \mathrm{~h}$. Sections were stained with uranyl acetate and lead citrate, and then observed with a Hitachi H-7650 TEM (Hitachi High Technologies, Tokyo, Japan).

The change of gene profiles in MCF-7 cells treated with EA. MCF-7 cells were plated at a density of $4 \times 10^{3}$ cells $/ \mathrm{cm}^{2}$ in T75 culture flasks. Synchronization was achieved as previously described. The cells were harvested at $80-90 \%$ confluency. After exposure to EA $(15 \mu \mathrm{g} / \mathrm{ml})$ for 6,12 and $24 \mathrm{~h}$, total RNAs of the cells were harvested using TRIzol reagent (Life Technologies, Carlsbad, CA, USA) and the RNeasy kit (Qiagen, Dusseldorf, Germany) according to manufacturer's instructions. For each time-point, two preparations of RNA samples were independently subjected to array hybridization. After having passed RNA measurement using the NanoDrop ND-1000 (NanoDrop Technologies, Wilmington, DE, USA) and denaturing gel electrophoresis, the samples were amplified and labeled using the Agilent Quick Amp labeling kit and hybridized with Agilent whole genome oligo-microarray in Agilent's SureHyb hybridization chambers. After hybridization and washing, the processed slides were scanned with the Agilent DNA microarray scanner using settings recommended by Agilent Technologies (Palo Alto, CA, USA).

The resulting text files extracted from Agilent Feature extraction software (version 10.5.1.1) were imported into the Agilent GeneSpring GX software (version 11.0) for further analysis. The microarray data sets were normalized in Agilent Feature extraction software, and then the genes recorded present in all the samples were chosen for further analysis. Differentially expressed genes were identified through foldchange screening.

The gene expression profiling experiment was successfully completed on the samples. The profiling identified a subset of the total number of probes analyzed by Agilent Whole Genome Oligo microarray that are differentially expressed. GO Analysis and Pathway Analysis were performed on this subset of genes. More detailed information was found in Gene Ontology (GO) report and Pathway Analysis report.

Real-time reverse transcription-PCR analysis. Total RNA from MCF-7 cells exposed to $15 \mu \mathrm{g} / \mathrm{ml}$ EA for 6,12 or $24 \mathrm{~h}$ were used for transcriptomics analysis by real-time reverse transcription-PCR (real-time RT-PCR) with selected target genes. Each $2 \mu \mathrm{g}$ of RNA was reversely transcribed to cDNA using oligo(dT) primers and SuperScript II reverse transcriptase kit (Life Technologies). Primers were designed using Primer 5 software and synthesized by Sangon Biotech Co., Ltd. (Shanghai, China). The primers are shown in Table I. Real-time RT-PCR reactions were then performed in a total of $25 \mu \mathrm{l}$ of reaction mixture using the ABI Prism $7900 \mathrm{HT}$ sequence detection system (Applied Biosystems, Foster City, CA, USA). Data were analyzed using the comparative $\mathrm{Ct}$ method and was normalized by GAPDH expression in each sample.

Western blot analysis. Western blot analysis was performed using the lysis buffer isolated protein. Briefly, $20 \mu \mathrm{g}$ of protein was resolved in 10-15\% SDS/PAGE and transferred to polyvinylidene fluoride membrane. The blots were blocked in blocking buffer overnight at $4^{\circ} \mathrm{C}$, and incubated with the primary antibody at $37^{\circ} \mathrm{C}$ for $1 \mathrm{~h}$. The antibody-antigen 
Table I. The primer used for real-time RT-PCR analysis.

\begin{tabular}{|c|c|}
\hline Genes & Primer sequenece \\
\hline$T G F \beta 1$ & $\begin{array}{l}\text { TGGAAACCCACAACGAAATCTATG } \\
\text { GCTAAGGCGAAAGCCCTCA }\end{array}$ \\
\hline$T G F \beta R I I$ & $\begin{array}{l}\text { AAAGGTCGCTTTGCTGAGGTCTA } \\
\text { GTCGTTCTTCACGAGGATATTGGA }\end{array}$ \\
\hline$T G F \beta R I$ & $\begin{array}{l}\text { TTCAAACGTGCTGACATCTATGC } \\
\text { TTCCTGTTGACTGAGTTGCGATA }\end{array}$ \\
\hline$S M A D 3$ & $\begin{array}{l}\text { ATGGCCGGTTGCAGGTGTC } \\
\text { GGTTCATCTGGTGGTCACTGGTTTC }\end{array}$ \\
\hline$p 21^{\text {Cipl }}$ & $\begin{array}{l}\text { TTAGCAGCGGAACAAGGAGT } \\
\text { AGAAACGGGAACCAGGACA }\end{array}$ \\
\hline$p 15^{\operatorname{Ink} 4 b}$ & $\begin{array}{l}\text { TGGTGGCTACGAATCTTCCG } \\
\text { TCGTCGCTTGCACATCCTC }\end{array}$ \\
\hline$p 19^{\operatorname{Ink} 4 d}$ & $\begin{array}{l}\text { CACCCTGAAGGTCCTAGTGGAG } \\
\text { AGTGGGCAGGAGAAACAAGAAG }\end{array}$ \\
\hline$p 57^{\text {Kip } 2}$ & $\begin{array}{l}\text { TCGGCTGGGACCGTTCA } \\
\text { TGTATGGCAGCTACAGCTTGTG }\end{array}$ \\
\hline$C C N D 1$ & $\begin{array}{l}\text { ATGTTCGTGGCCTCTAAGATGAAG } \\
\text { GTGTTTGCGGATGATCTGTTTGT }\end{array}$ \\
\hline$C C N E$ & $\begin{array}{l}\text { CAGTTTGCGTATGTGACAGATGGA } \\
\text { GAGAAATGATACAAGGCCGAAGC }\end{array}$ \\
\hline CCNA2 & $\begin{array}{l}\text { ATGATGAGCATGTCACCGTTCC } \\
\text { TCCATTGGATAATCAAGAGGGACC }\end{array}$ \\
\hline p107 & $\begin{array}{l}\text { AGAACCACCAAAGTTACCACGAA } \\
\text { TCTTCAGAAGCCGTAAAGTCAGC }\end{array}$ \\
\hline p130 & $\begin{array}{l}\text { AGAAGGGTGACTGAAGTTCGTG } \\
\text { CAACATTGACTTGGACAGGGAAG }\end{array}$ \\
\hline$R B 1$ & $\begin{array}{l}\text { AAAGGACCGAGAAGGACCAACT } \\
\text { CAGACAGAAGGCGTTCACAAAGT }\end{array}$ \\
\hline$E 2 F 1$ & $\begin{array}{l}\text { ССССААСТСССТСТАСССТТ } \\
\text { СТСТСССАТСТСАТАТССАТССТG }\end{array}$ \\
\hline$E 2 F 2$ & $\begin{array}{l}\text { CTGGAGTGCAGTGGCCTGAT } \\
\text { TGGCTCGTGCCTGTCATCTC }\end{array}$ \\
\hline GAPDH & $\begin{array}{l}\text { GGTGAAGGTCGGAGTCAACGG } \\
\text { CCTGGAAGATGGTGATGGGATT }\end{array}$ \\
\hline
\end{tabular}

complexes were then detected with alkaline phosphataseconjugated anti-rabbit or anti-mouse IgG secondary antibodies using a BCIP/NBT Alkaline Phosphatase Color Development kit. The band was recorded by a digital camera and analyzed by ImageJ software (NIH, Bethesda, MD, USA). The results were normalized with $\beta$-actin. The following monoclonal antibodies were used in the present study (source): anti- $\beta$ actin (Sigma Chemical), anti-Smad3, anti-p21 ${ }^{\text {Cipl }}$ (Boshide Co., Wuhan, China), anti-phospho-Smad3 (Santa Cruz Biotechnology, Santa Cruz, CA, USA), anti-Rb, anti-phospho$\mathrm{Rb}$, anti-TGF $\beta 1$, anti-T $\beta R$ I and anti-T $\beta R$ II (Cell Signaling Technology, Beverly, MA, USA).

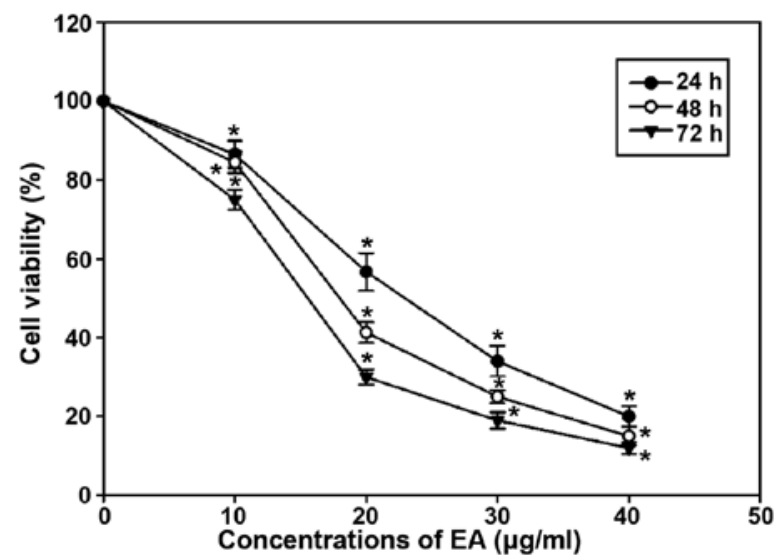

Figure 1. Effect of EA on the growth of MCF-7 cells. MCF-7 cells were exposed to increasing dosages of EA for 24,48 or $72 \mathrm{~h}$. The cell viability was expressed as the percentage of control group (DMSO). The data are presented as mean $\pm \mathrm{SD}, \mathrm{n}=6$ per group. ${ }^{*} \mathrm{P}<0.05$ compared to the vehicle control.

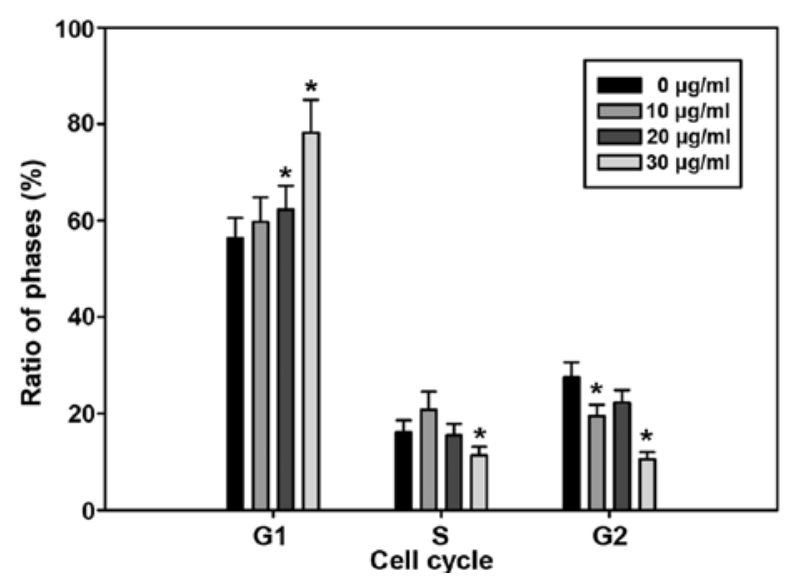

Figure 2. Effect of EA on MCF-7 cell cycle distribution. MCF-7 cells were treated with different concentrations of EA and subjected to flow cytometric analysis. The percentage of each phase is indicated in the panel. The results were representative of three independent experiments. ${ }^{*} \mathrm{P}<0.05$ compared to the vehicle control.

Statistical analysis. The Student's t-test was used to determine the significance between treatments and untreated controls, and $\mathrm{P}<0.05$ was considered significant.

\section{Results}

The effects of EA on cell proliferation in MCF-7 cells. The inhibitory effect of EA on cell proliferation in MCF-7 cells was assessed by MTT assay. As shown in Fig. 1, EA suppressed MCF-7 cell growth in a time- and dose-dependent manner. The inhibitory response was apparent as early as $24 \mathrm{~h}$ with a concentration range of EA from 10 to $40 \mu \mathrm{g} / \mathrm{ml} \mathrm{EA}$ was found to reduce the cell number to 13.5 and $80 \%$ of the untreated control at concentrations of 10 and $40 \mu \mathrm{g} / \mathrm{ml}$, respectively.

Cell cycle arrest at G0-G1 phase by EA. To determine whether decreased cell number accumulation was related to cell cycle arrest treated by EA, we assessed the effect of EA on cell cycle perturbation by flow cytometry. The data in Fig. 2 clearly showed a significant block in G0-G1 phase of the cell 

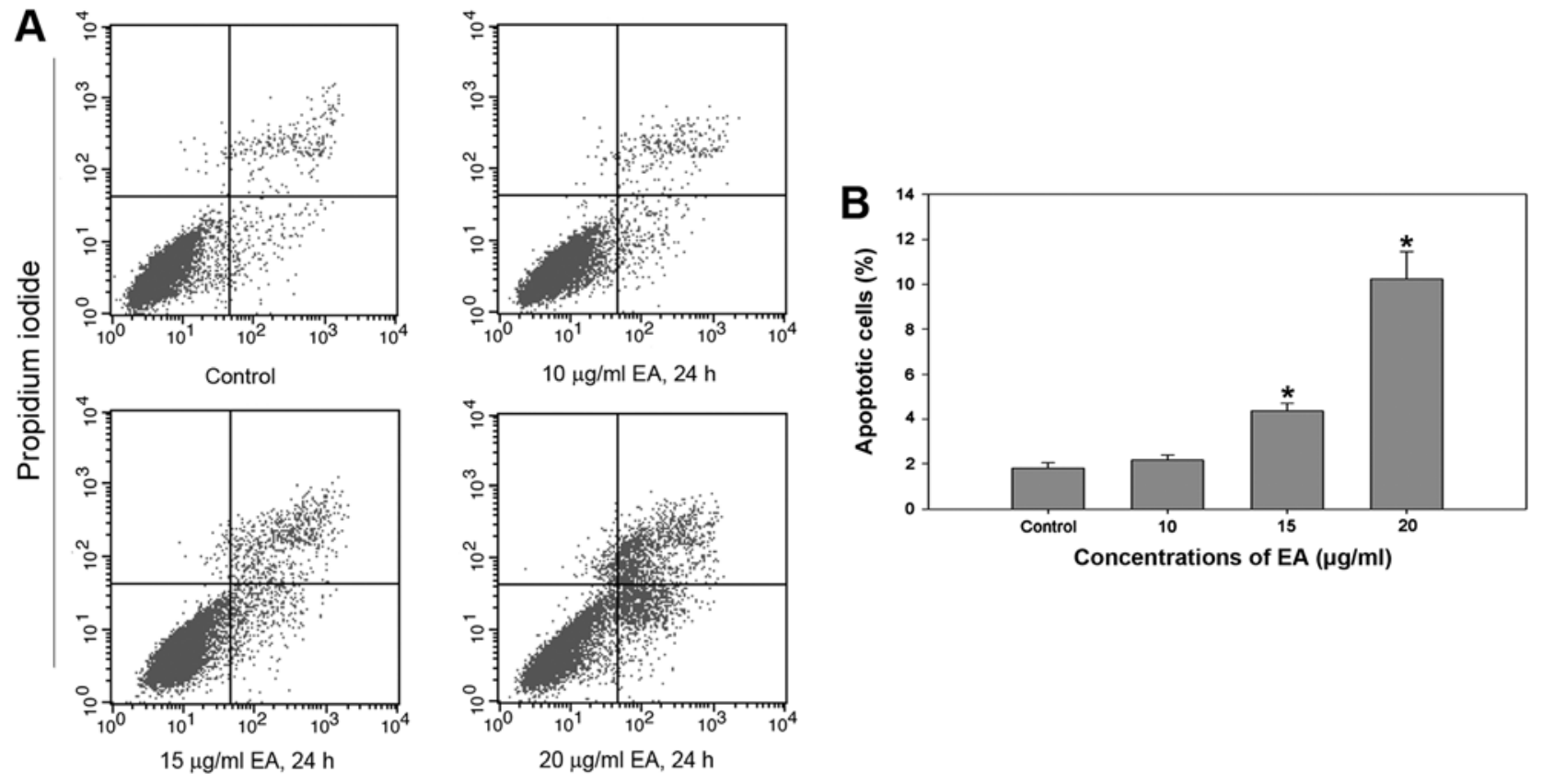

Concentrations of EA $(\mu \mathrm{g} / \mathrm{mI})$

Annexin V

Figure 3. Effect of EA on apoptosis in MCF-7 cells. (A and B), MCF-7 cells were untreated and treated with increasing concentrations of EA for $24 \mathrm{~h}$. Percentage of apoptotic cells were determined by staining with Annexin V and PI.


Figure 4. Morphology and ultrastructure of MCF-7 cells were analyzed by TEM. MCF-7 cells were treated with EA (15 $\mu \mathrm{g} / \mathrm{ml})$ for $24 \mathrm{~h}$ and examined by TEM at magnification x10,000. (A) In the control cells, the structure of the nucleus, abundance of cytoplasm, as well as the size and shape of the mitochondria, were all normal. (B) In the treated cells, the compaction and margination of nuclear chromatin were quite obvious. (C) Cell detachment, cell shrinkage, folded nuclear membrane, membrane blebbing, increased nuclear heterochromatin, swelling of the endoplasmic reticulum cisternae and vesicle formation (abundant vacuoles with multivesicular bodies) were observed. (D) Nuclear pyknosis and fragmentation occurred. 
Table II. Fold-changes of specific genes in MCF-7 cells treated with EA.

$\mathrm{MCF}-7$

Genes

\begin{tabular}{llll} 
& & $\mathrm{MCF}-7$ & \\
\cline { 2 - 3 } (6h & $12 \mathrm{~h}$ & $24 \mathrm{~h}$ \\
$\mathrm{NC}$ & $\mathrm{NC}$ & $\mathrm{NC}$ \\
$\mathrm{NC}$ & $\mathrm{NC}$ & $\mathrm{NC}$ \\
$\mathrm{NC}$ & $\mathrm{NC}$ & $\mathrm{NC}$ \\
$\mathrm{NC}$ & $\mathrm{NC}$ & $\mathrm{NC}$ \\
$\mathrm{NC}$ & $\mathrm{NC}$ & 2.7 \\
$\mathrm{NC}$ & 3.4 & 4.8 \\
$\mathrm{NC}$ & $\mathrm{NC}$ & 4.8 \\
$\mathrm{NC}$ & $\mathrm{NC}$ & 2.8 \\
$\mathrm{NC}$ & $\mathrm{NC}$ & 0.3 \\
$\mathrm{NC}$ & 0.5 & 2.1 \\
2.4 & $\mathrm{NC}$ & $\mathrm{NC}$ \\
2.3 & $\mathrm{NC}$ & 0.3 \\
$\mathrm{NC}$ & $\mathrm{NC}$ & 0.3 \\
$\mathrm{NC}$ & $\mathrm{NC}$ & 0.4 \\
$\mathrm{NC}$ & $\mathrm{NC}$ & $\mathrm{NC}$ \\
$\mathrm{NC}$ & $\mathrm{NC}$ & 0.5 \\
$\mathrm{NC}$ & 0.5 & 0.2 \\
$\mathrm{NC}$ & $\mathrm{NC}$ & 0.4 \\
\hline & &
\end{tabular}

NM_000660.4, transforming growth factor, $\beta 1$ (TGF $\beta 1)$

NM_001024847, transforming growth factor, $\beta$ receptor II (TGF $\beta R I I)$

NM_004612.2, transforming growth factor, $\beta$ receptor 1 (TGF $\beta R I)$

NM_005901.4,SMAD family member 2 (SMAD2)

NM_005902.3, SMAD family member 3 (SMAD3)

NM_000389.1,CDK inhibitor 1A (p2 $\left.1^{\text {Cipl }}\right)$

NM_078487.3, cyclin-dependent kinase inhibitor 2B $\left(p 15^{\operatorname{Ink} 4 b}\right)$

NM_001800.3, cyclin-dependent kinase inhibitor 2D ( $\left.p 19^{\text {Ink4d }}\right)$

NM_000076.2, cyclin-dependent kinase inhibitor 1C ( $\left.p 57^{\text {Kip } 2}\right)$

NM_053056.2, cyclin D1 (CCND1)

NM_001238, cyclin E 1 (CCNE1)

2.4

NM_057749, cyclin E 2 (CCNE2)

NM_001237.3, cyclin A2 (CCNA2)

NM_002895.2, retinoblastoma-like 1 (p107)

NM_005611.3, retinoblastoma-like 2 (p130)

NM_000321.2, retinoblastoma $1(R B 1)$

NM_005225.2, E2F transcription factor $1(E 2 F 1)$

NM_004091.3,E2F transcription factor 2 (E2F2)

$\mathrm{NC}$, no change. $<1$, decrease; $>1$, increase.

cycle. The increase in the G0-G1 population was accompanied by a delay of passage of cells to $S$ phase. Synchronized control cells that were not treated by EA moved into $\mathrm{S}$ phase.

Effect of EA on cell apoptosis. In order to determine whether EA could induce cell apoptosis, FCM and TEM were conducted in EA-treated MCF-7 cells and the control. FCM showed that the cell apoptotic rates were $4.36 \pm 0.35$ and $10.24 \pm 1.23$ after treatment with 15 or $20 \mu \mathrm{g} / \mathrm{ml}$ of EA for $24 \mathrm{~h}$, respectively. MCF-7 cells treated with increasing concentrations of EA exhibited a significant increase in the apoptotic cell fraction, indicating apoptosis induction (Fig. 3).

Morphological and ultra-structural characteristics of apoptosis in MCF-7 cells exposed to EA for $24 \mathrm{~h}$ were examined by transmission electron microscope (TEM) (Fig. 4).

Profiling of EA-responsive genes by cDNA microarray anal$y$ sis. We found a total of 4,738 genes that showed a $>2.0$-fold change after $24 \mathrm{~h}$ of EA treatment. Among these genes, 2,547 genes were downregulated and 2,191 genes were upregulated in EA-treated MCF-7 cells. The altered expressions of many genes did not occurr after $6 \mathrm{~h}$ of EA treatment and changes were evident with $24 \mathrm{~h}$ of treatment (Table II).

After clustering based analysis and pathway analysis according to their biological functions, several genes, which are related to cell cycle, apoptosis and DNA replication were found increased or decreased (Fig. 5). Especially, TGF- $\beta$ /Smads pathway was found as the potential pathway, by which EA induced cell cycle arrest in G0/G1 phase and educed the inhibitory effect on MCF-7 cells (Fig. 6).

Detection of EA-responsive genes by real-time RT-PCR and western blots. The next step was to confirm the changes of a subset of 16 genes that showed pronounced regulation in TGF- $\beta$ /Smads pathway by real-time RT-PCR and/or western blot analysis. We examined the genes (TGF- $\beta 1$, T $\beta R-I$, T $\beta$ R-II, Smad3, $p 15^{\text {Ink4b }}, p 19^{\text {Ink4d }}, p 21 C^{\text {ip1 }}, p 7^{\text {Kip2 }}$, cyclin D1, cyclin E, cyclin A2, E2F1, E2F2, Rb1, $p 107$ and $p 130$ ) by real-time RT-PCR and some proteins (TGF- $\beta 1$, T $\beta$ R-I, T $\beta$ R-II, Smad3, $p$-Smad3, Rb1, $p$-Rb1 and $p 21^{\text {Cipl }) ~ b y ~ w e s t e r n ~}$ blots. We were able to verify eight proteins by western blot analysis and ten RNAs by real-time RT-PCR. This represents a success rate of $75 \%$ (12 out of 16). The results are shown in Fig. 7, respectively. The lack of complete concordance could be attributable to either false positive signals of the array data or the discrepancy between transcript and protein expression. There was a noteworthy observation. A decreased level of cyclin D1 was found at $12 \mathrm{~h}$, but an upregulation of cyclin D1 expression was detected by cDNA microarray, real-time RT-PCR and western blot analyses at $24 \mathrm{~h}$. Cells lacking cyclin D1 are known to stay in cell G0-G1 arrest $(12,13)$. It is possible that at the early time-point, the repression of cyclin D1 was necessary for initiating EA-mediated cell cycle arrest, whereas at the later time-point when G0-G1 arrest was firmly established, cells produced more cyclin D1 for apoptosis to advance (14). 


\section{Sig pathway of DE gene}

Cell cycle - Homo sapiens (human)

Steroid biosynthesis - Homo sapiens (human)

Lysosome - Homo sapiens (human)

Spliceosome - Homo sapiens (human)

PPAR signaling pathway - Homo sapiens (human)

Protein processing in endoplasmic reticulum - Homo sapiens (human)

Other glycan degradation - Homo sapiens (human)

Purine metabolism - Homo sapiens (human)

Ubiquitin mediated proteolysis - Homo sapiens (human)

SNARE interactions in vesicular transport - Homo sapiens (human)

DNA replication - Homo sapiens (human)


Figure 5. Pathway analysis of specific genes in MCF-7 cells treated with EA.

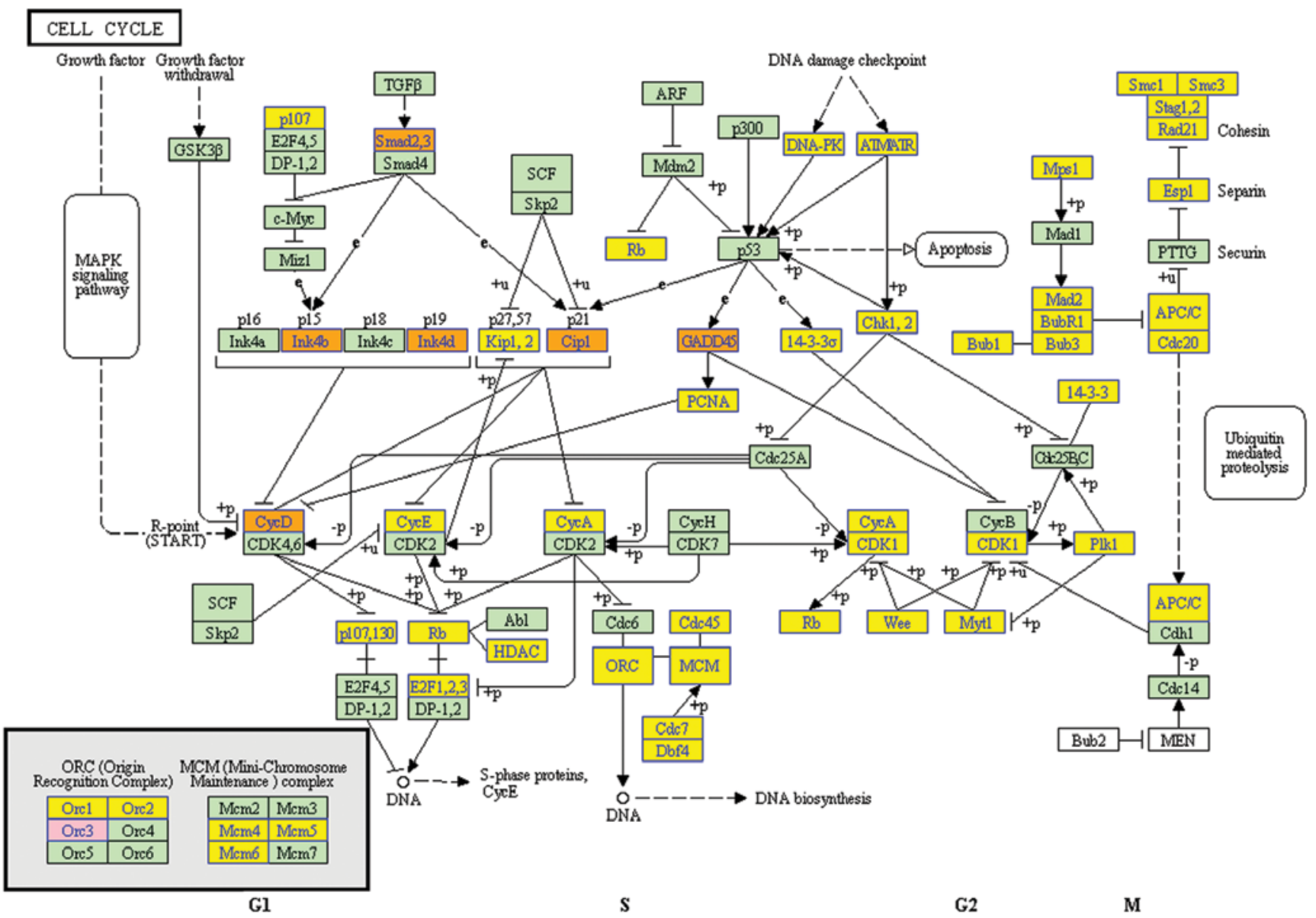

Figure 6. The change of genes in TGF- $\beta$ /Smads pathway in MCF-7 cells treated with EA. Green indicates no change, yellow indicates downregulation and brown indicates upregulation. 



Figure 7. (A) The changes of a subset of genes in TGF- $\beta /$ Smads pathway in MCF-7 cells treated with $15 \mu \mathrm{g} / \mathrm{ml}$ of EA for $24 \mathrm{~h}$ by real-time RT-PCR. (B) The changes of a subset of proteins in TGF- $\beta /$ Smads pathway of MCF-7 cells treated with $15 \mu \mathrm{g} / \mathrm{ml}$ of EA for 6,12 and $24 \mathrm{~h}$ by western blot analysis.

\section{Discussion}

To understand the molecular mechanisms leading to EA-induced growth inhibition on MCF-7 cells, in this study, cDNA microarray was used to elucidate the changes in gene expression profile. On the basis of the collection of $41,000^{+}$ genes screened by the whole human genome oligo microarray of Agilent, 4,738 genes were identified responsive to EA treatment for $24 \mathrm{~h}$. These genes are responsible for cell cycle arrest, apoptosis, steroid biosynthesis, lysosome, splicesome, protein processing in endoplasmic reticulum and DNA replication. TGF- $\beta /$ Smads pathway was found to be the target through pathway analysis, by which EA educed the inhibitory effect on the growth of MCF-7 cells. In order to confirm the result of cDNA microarray, 16 genes belonging to TGF- $\beta /$ Smads pathway were further characterized by either western blots or real-time RT-PCR. On the basis of the results obtained from the present study, we proposed that TGF- $\beta /$ Smads signaling pathways could mediate the outcome of EA-induced cell cycle arrest.

Our results also showed that cyclins (cyclin A2 and cyclin E2) were downregulated in EA-treated MCF-7 cells, whereas cyclin-dependent kinase $(\mathrm{Cdk})$ inhibitors $\left(p 21^{\mathrm{Cip} 1}\right.$, $p 15$ and $p 19)$ were upregulated. These results suggest that EA inhibited the growth of breast cancer cell through the arrest of the cell cycle and inhibition of proliferation. Driving of the cell cycle through one phase to the other is tightly controlled by complex network events of cyclins, Cdk and transcription factors (15). During mid G1 phase, cdk4 and cdk6 interact with $\mathrm{D}$ type cyclins to form heterodimer kinase complex. This event follows the interaction of cyclin $\mathrm{E}$ with cdk2 to phosphorylate Rb in the late G1 phase (16-18). The cdk inhibitors, including $p 21^{\mathrm{Cip} 1}, p 15$ and $p 19$, have been shown to inhibit activity of cyclin-cdk complex to decrease phosphorylation of $\mathrm{Rb}$. Phosphorylation of $\mathrm{Rb}$ has been shown to be critical for the stabilization of active E2F1 to translocate into the nucleus and transcribe various genes required for the entry of the cell from G1 to $S$ phase (19).

TGF- $\beta$ /Smads signaling pathway is involved in a broad spectrum of biological responses throughout embryonic development and adult life, including cell proliferation, differentiation, epithelial-to-mesenchymal transition, apoptosis and angiogenesis $(20,21)$. Transforming growth factor- $\beta$ (TGF- $\beta$ ) is a member of the TGF- $\beta$ superfamily. The cytokine signals carried by TGF- $\beta$ were transmitted through a heterogenic complex of type I and type II serine/threonine kinase receptors (T $\beta R$-I and T $\beta R$-II). Activation of the receptor complex through ligand binding results in the phosphorylation of the T $\beta R$-I by the T $\beta R$-II. Subsequently, active T $\beta$ R-I phosphorylate receptor-regulated Smads (R-Smads), which are intracellular transducers of TGF- $\beta$ signals, including Smad 2 and Smad3. Phosphorylated R-Smads then associate with Smad4, the common Smad (Co-Smad) and shuttle to the nucleus. The complexes interact with a large repertoire of transcription factors and result in corresponding biological function subsequently (22-25). TGF- $\beta$ has been described as a potent tumor 
suppressor for promoting cell growth inhibition, apoptosis and differentiation $(26,27)$. Mutations in the components of the TGF- $\beta$ signaling cascade have been identified in a number of human cancers, including hereditary non-polyposis colon cancer, hepatocellular carcinoma, and pancreatic and ovarian cancers (28).

TGF- $\beta 1$ is a potent inhibitor of cell proliferation. TGF- $\beta 1$ induced arrest occurs during G1 and is mediated by Smad proteins, which regulate transcriptional targets, including c-myc (29-31). Downregulation of c-myc allows induction of $p 15^{\text {Ink4b }}$, which inhibits Cdk4-cyclin D $(32,33)$. The $p 27^{\mathrm{Kipl}}$ inhibitor is also utilized by TGF- $\beta 1$ to inhibit Cdk2cyclin E (34). Cdk suppression prevents hyperphosphorylation of $\mathrm{Rb}$ (18), causing $\mathrm{Rb}$ to remain in a hypophosphorylated, growth-suppressive form (35).

TGF- $\beta 1$ inhibits the growth of cells of epithelial origin by downregulating components of the cell cycle and upregulating cell cycle inhibitors (36). In most epithelial cell types TGF- $\beta 1$ acts in late G1 phase and prevents further progression to the G1/S phase transition (37). Cdks and cyclin complexes phosphorylate specific target molecules, such as the retinoblastoma proteins pRb, p107 and p130 (38). The Cdk inhibitors mediate cell cycle arrest at different points of G1 (39). TGF- $\beta 1$ inhibitory actions in late G1 phase are mediated in part by the inhibition of cyclin D1 and cyclin E expression which prevents Cdk kinase activity resulting in RB hypophosphorylation $(40,41)$ and/or by the upregulation the expression of various Cdk inhibitors such as p21 and p27 (42). The transcription factor E2F regulates the expression of $S$ and $G 2$ phase cyclins such as cyclins E, A and B (43). Hypophosphorylated Rb binds to and represses $\mathrm{E} 2 \mathrm{~F}$ by recruiting histone deacetylases and forming a repressor complex at E2F-responsive promoters to block transcription of cyclins necessary for cell cycle progression $(44,45)$.

In the present study, we found that EA inhibits the proliferation of $\mathrm{MCF}-7$ breast cancer cells mainly mediated by arresting cell cycle in the G0/G1 phase. TGF- $\beta$ /Smads signaling pathway was further found as the potential molecular mechanism of EA to regulate cell cycle arrest in vitro. Therefore, the regulation of TGF- $\beta /$ Smads pathway in breast cancer cells could be a novel therapeutic approach for treatment of patients with breast cancer. Further studies with in vivo models, as well as an analysis of additional human samples are still needed to confirm the molecular mechanisms of EA in inhibition or prevention of breast cancer growth.

\section{Acknowledgements}

The present study was supported by the National Natural Science Foundation of China (nos. 81372612 and 81302059), the Outstanding Youth Science Foundation of Heilongjiang Province (no. JC201203), the Study Abroad Returnees Science Foundation of Heilongjiang (no. LC201009), and the Natural Science Foundation of Heilongjiang province (no. H201425).

\section{References}

1. Jemal A, Bray F, Center MM, Ferlay J, Ward E and Forman D Global cancer statistics. CA Cancer J Clin 61: 69-90, 2011.
2. Dai Z, Nair V, Khan M and Ciolino HP: Pomegranate extract inhibits the proliferation and viability of MMTV-Wnt-1 mouse mammary cancer stem cells in vitro. Oncol Rep 24: 1087-1091, 2010.

3. Larrosa M, Tomas-Barberan FA and Espin JC: The dietary hydrolysable tannin punicalagin releases ellagic acid that induces apoptosis in human colon adenocarcinoma Caco-2 cells by using the mitochondrial pathway. J Nutr Biochem 17: 611-625, 2006.

4. Seeram NP, Adams LS, Henning SM, et al: In vitro antiproliferative, apoptotic and antioxidant activities of punicalagin, ellagic acid and a total pomegranate tannin extract are enhanced in combination with other polyphenols as found in pomegranate juice. J Nutr Biochem 16: 360-367, 2005.

5. Herrera MC and Luque de Castro MD: Ultrasound-assisted extraction for the analysis of phenolic compounds in strawberries. Anal Bioanal Chem 379: 1106-1112, 2004.

6. Tsao DA, Chang HJ, Lin CY, et al: Gene expression profiles for predicting the efficacy of the anticancer drug 5-fluorouracil in breast cancer. DNA Cell Biol 29: 285-293, 2010.

7. Berger E, Rome S, Vega N, Ciancia C and Vidal H: Transcriptome profiling in response to adiponectin in human cancer-derived cells. Physiol Genomics 42A: 61-70, 2010.

8. Poulogiannis G, Luo F and Arends MJ: RAS signalling in the colorectum in health and disease. Cell Commun Adhes 19: 1-9, 2012.

9. Areshkov PO, Avdieiev SS, Balynska OV, Leroith D and Kavsan VM: Two closely related human members of chitinaselike family, CHI3L1 and CHI3L2, activate ERK1/2 in 293 and U373 cells but have the different influence on cell proliferation. Int J Biol Sci 8: 39-48, 2012.

10. Huang KF, Zhang GD, Huang YQ and Diao Y: Wogonin induces apoptosis and down-regulates survivin in human breast cancer MCF-7 cells by modulating PI3K-AKT pathway. Int Immunopharmacol 12: 334-341, 2012.

11. Rodriguez-Berriguete G, Fraile B, Martinez-Onsurbe P, Olmedilla G, Paniagua R and Royuela M: MAP kinases and prostate cancer. J Signal Transduct 2012: 169170, 2012.

12. Wang CY, Tsai AC, Peng CY, et al: Dehydrocostuslactone suppresses angiogenesis in vitro and in vivo through inhibition of Akt/GSK-3beta and mTOR signaling pathways. PLoS One 7: e31195, 2012.

13. Cirera-Salinas D, Pauta M, Allen RM, et al: Mir-33 regulates cell proliferation and cell cycle progression. Cell Cycle 11: 922-933, 2012.

14. Dong Y, Ganther HE, Stewart C and Ip C: Identification of molecular targets associated with selenium-induced growth inhibition in human breast cells using cDNA microarrays. Cancer Res 62: 708-714, 2002.

15. Uhlmann F, Bouchoux C and Lopez-Aviles S: A quantitative model for cyclin-dependent kinase control of the cell cycle: revisited. Philos Trans R Soc Lond B Biol Sci 366: 3572-3583, 2011.

16. Yu B, Lane ME and Wadler S: SU9516, a cyclin-dependent kinase 2 inhibitor, promotes accumulation of high molecular weight E2F complexes in human colon carcinoma cells. Biochem Pharmacol 64: 1091-1100, 2002.

17. Maiti B, Li J, de Bruin A, et al: Cloning and characterization of mouse E2F8, a novel mammalian E2F family member capable of blocking cellular proliferation. J Biol Chem 280: 18211-18220, 2005.

18. Cheng L, Rossi F, Fang W, Mori T and Cobrinik D: Cdk2dependent phosphorylation and functional inactivation of the pRB-related p130 protein in pRB(-), p16 $6^{\mathrm{INK} 4 \mathrm{~A}}(+)$ tumor cells. J Biol Chem 275: 30317-30325, 2000.

19. Muller H, Moroni MC, Vigo E, Petersen BO, Bartek J and Helin $\mathrm{K}$ : Induction of S-phase entry by E2F transcription factors depends on their nuclear localization. Mol Cell Biol 17: 5508-5520, 1997.

20. Gui T, Sun Y, Shimokado A and Muragaki Y: The roles of mitogen-activated protein kinase pathways in TGF-beta-induced epithelial-mesenchymal transition. J Signal Transduct 2012: 289243, 2012.

21. Pardali E and Ten Dijke P: TGFbeta signaling and cardiovascular diseases. Int J Biol Sci 8: 195-213, 2012.

22. Attisano L and Wrana JL: Signal transduction by the TGF-beta superfamily. Science 296: 1646-1647, 2002.

23. Feng XH and Derynck R: Specificity and versatility in tgf-beta signaling through Smads. Annu Rev Cell Dev Biol 21: 659-693, 2005. 
24. Siegel PM and Massague J: Cytostatic and apoptotic actions of TGF-beta in homeostasis and cancer. Nat Rev Cancer 3: 807-821, 2003.

25. Moustakas A, Souchelnytskyi S and Heldin $\mathrm{CH}$ : Smad regulation in TGF-beta signal transduction. J Cell Sci 114: 4359-4369, 2001.

26. de Caestecker MP, Piek E and Roberts AB: Role of transforming growth factor-beta signaling in cancer. J Natl Cancer Inst 92: 1388-1402, 2000.

27. Derynck R, Akhurst RJ and Balmain A: TGF-beta signaling in tumor suppression and cancer progression. Nat Genet 29: $117-129,2001$.

28. Levy L and Hill CS: Alterations in components of the TGF-beta superfamily signaling pathways in human cancer. Cytokine Growth Factor Rev 17: 41-58, 2006.

29. Chen CR, Kang Y, Siegel PM and Massague J: E2F4/5 and p107 as Smad cofactors linking the TGFbeta receptor to c-myc repression. Cell 110: 19-32, 2002.

30. Coffey RJ Jr, Bascom CC, Sipes NJ, Graves-Deal R, Weissman BE and Moses HL: Selective inhibition of growth-related gene expression in murine keratinocytes by transforming growth factor beta. Mol Cell Biol 8: 3088-3093, 1988.

31. Pietenpol JA, Holt JT, Stein RW and Moses HL: Transforming growth factor beta 1 suppression of c-myc gene transcription: role in inhibition of keratinocyte proliferation. Proc Natl Acad Sci USA 87: 3758-3762, 1990.

32. Hannon GJ and Beach D: p15INK4B is a potential effector of TGF-beta-induced cell cycle arrest. Nature 371: 257-261, 1994.

33. Warner BJ, Blain SW, Seoane J and Massague J: Myc downregulation by transforming growth factor beta required for activation of the $\mathrm{p} 15^{\mathrm{Ink} 4 \mathrm{~b}} \mathrm{G}_{1}$ arrest pathway. Mol Cell Biol 19: 5913-5922, 1999.

34. Polyak K, Kato JY, Solomon MJ, et al: p27Kip1, a cyclin-Cdk inhibitor, links transforming growth factor-beta and contact inhibition to cell cycle arrest. Genes Dev 8: 9-22, 1994.
35. Laiho M, DeCaprio JA, Ludlow JW, Livingston DM and Massague J: Growth inhibition by TGF-beta linked to suppression of retinoblastoma protein phosphorylation. Cell 62: 175-185, 1990.

36. Ramos C, Becerril C, Montano M, et al: FGF-1 reverts epithelial-mesenchymal transition induced by TGF- $\{$ beta 1 through MAPK/ERK kinase pathway. Am J Physiol Lung Cell Mol Physiol 299: L222-L231, 2010.

37. Derynck R: TGF-beta-receptor-mediated signaling. Trends Biochem Sci 19: 548-553, 1994.

38. Claudio PP, Tonini T and Giordano A: The retinoblastoma family: twins or distant cousins? Genome Biol 3: reviews3012, 2002 .

39. Coqueret O: New roles for $\mathrm{p} 21$ and $\mathrm{p} 27$ cell-cycle inhibitors: a function for each cell compartment? Trends Cell Biol 13: 65-70, 2003.

40. Ko TC, Sheng HM, Reisman D, Thompson EA and Beauchamp RD: Transforming growth factor-beta 1 inhibits cyclin D1 expression in intestinal epithelial cells. Oncogene 10: $177-184,1995$.

41. Massague $\mathbf{J}$ and Polyak K: Mammalian antiproliferative signals and their targets. Curr Opin Genet Dev 5: 91-96, 1995.

42. Robson CN, Gnanapragasam V, Byrne RL, Collins AT and Neal DE: Transforming growth factor-beta1 up-regulates p15, p21 and p27 and blocks cell cycling in G1 in human prostate epithelium. J Endocrinol 160: 257-266, 1999.

43. Cam H and Dynlacht BD: Emerging roles for E2F: beyond the G1/S transition and DNA replication. Cancer Cell 3: 311-316, 2003.

44. Brehm A, Miska EA, McCance DJ, Reid JL, Bannister AJ and Kouzarides T: Retinoblastoma protein recruits histone deacetylase to repress transcription. Nature 391: 597-601, 1998.

45. Magnaghi-Jaulin L, Groisman R, Naguibneva I, et al: Retinoblastoma protein represses transcription by recruiting a histone deacetylase. Nature 391: 601-605, 1998. 